\title{
UPAYA PENINGKATAN HASIL BELAJAR SOSIOLOGI MELALUI METODE DISKUSI KELOMPOK SISWA KELAS XI SMAN 12 MAKASSAR
}

\author{
AKHIRUDDIN, ROSNATANG \\ akhiruddinudin@ymail.com, rosnatang89@gmail.com \\ DOSEN STKIP MEGA REZKY MAKASSAR
}

\begin{abstract}
Improving sociology learning outcomes throuhg group discussion method of the Eleventh Grade Students of SMAN 12 of Makassar.

This research aimed to know improving sociology learning outcomes through group discussion method of the Eleventh Grade Students of SMAN 12 Makassar.

The type of research was Classroom Action Research (CAR) which consists of two cycles; each cycle was held during four times. Research procedure include planning, action, observation and reflection. Subject of the research was the eleventh grade students of SMAN 12 of Makassar.

The result of research showed that after applying group discussion method of sociology learning of the eleventh grade student of SMAN 12 Makasar that from cycle I to cycle II there was improving of students' learning outcomes. For the cycle I, there were 2 students $(6,67 \%)$ who had low category, there were 14 students $(46,67 \%)$ who had moderate category, there were 12 students $(40 \%)$ who had high category and there were 2 students $(6,6 \%)$ who had very category. While for cycle II students learning outcomes increased, there were 17 students $(56,67 \%)$ who had high category amd there were 13 students $(43,33 \%)$ who had very high category.
\end{abstract}

Key words: group discussion and learning outcomes

\section{A. PENDAHULUAN}

\section{Latar Belakang}

Pendidikan merupakan usaha sadar untuk menyiapkan peserta didik melalui kegiatan bimbingan, pengajaran atau latihan bagi peranannya dimasa yang akan datang. Pendidikanya mempunyai posisi strategis dalam rangka peningkatan kualitas sumber daya manusia, posisi yang strategis tersebut dapat tercapai apabila pendidikan yang dilaksanakan mempunyai kualitas. Kualitas pendidikan dapat diketahui dari dua hal yaitu: kualitas proses dan produk (Sudjana, 2000:35).

Suatu pendidikan dikatakan berkualitas proses apabila proses belajar mengajar dapat berlangsung secara efektif dan peserta didik mengalami proses pembelajaran yang bermakna. Pendidikan disebut berkualitas produk apabila peserta didik 
menunjukkan tingkat penguasaan yang tinggi terhadap tugas-tugas belajar sesuai dengan sasaran dan tujuan pendidikan. Hal ini dlihat pada hasil belajar yang dinyatakan dalam proses akademik. Pendidikan dikatakan berkualitas apabila terjadi penyelenggaraan pembelajaran yang efektif dan efisien dengan melibatkan semua komponen-komponen pendidikan, seperti mencakup tujuan pengajaran, pendidik dan peserta didik, bahan pelajaran, strategi/ metode belajar mengajar, alat dan sumber pelajaran serta evaluasi (Sugito, 1994:3).

Untuk itulah dalam pengajaran sosiologi harus dapat membawah anak didik kepada kenyataan hidup sebenarnya yang dapat dihayati mereka, ditanggapinya, dianalisisnya akhirnya dapat membina kepekaan sikap mental, keterampilan dalam menghayati kehidupan yang nyata ini. Pembelajaran sosiologi diajarkan mulai dari tingkat sekolah menengah atas sampai berpendidikan tinggi. Pendidik yang memiliki kompetensi tinggi mampu mendorong peserta didik meraih prestasi yang optimal. Oleh karena itu pembelajaran harus berorientasi pada peserta didik, karena peserta didik merupakan komponen pokok dan subyek didik. Sedangkan pendidik berfungsi sebagai pendorong, pembimbing, pengarah, pembina pertumbuhan dan perkembangan peserta didik (Usman, 1999:21). Ada beberapa pertimbangan yang harus dilihat oleh pendidik dalam menentukan metode pengajaran yang akan dipakai, anatara lain adalah: (1) Tujuan pengajaran (2) Karakteristik peseta didik (3) Besar kecilnya kelas (4) Bahan dan alat yang tersedia (5) Isi bahan pelajaran (6) Kemampuan pendidik (7) Evaluasi yang akan digunakan (Sugito, 1999:3)

Seiring hal tersebut, tidak terlepas dari penguasaan materi pelajaran sosiologi pada siswa kelas XI SMAN 12 Makassar. Berdasarkan hasil observasi tersebut dimana guru bidang studi hanya menggunakan metode-metode yang kurang termotivasi siswa sehingga berdampak pada hasil belajarnya, Adanya kekurangan dalam pembelajaran sosiologi ini, penulis refleksikan pada diri sendiri mengenai sebab-sebabnya. Kemudian dibuat catatan untuk merancang suatu kegiatan perbaikan pembelajaran, agar proses pembelajaran sosiologi menjadi bermakna,dan tidak membosankan diperluakan model pembelajan yang berorientasi pada peserta didik, dapat melibatkan peserta didik secara aktif, dan peserta didik dapat menggunakan pengetahuan yang telah dimilikinya untuk mengkonstruksi pengetahuan baru, maka perlu adanya suatu pembelajaran atau metode tertentu yang dapat meningkatkan kemampuan peserta didik dan hasil belajarnya meningkat. 
Salah satu metode pembelajaran yang berpusat pada peserta didik adalah metode diskusi kelompok. Dalam metode diskusi kelompok ini terdapat saling ketergantungan antara pesrta didik untuk mencapai tujuan pembelajaran. setiap peserta didik mempunyai kesempatan yang sama untuk sukses. Aktivitas belajar berpusat padapeserta didik dalam bentuk diskusi. Metode ini menuntut para peserta didik untuk memiliki kemampuan yang baik dalam berkomunikasi maupun dalam keterampilan proses kelompok.

\section{Rumusan Masalah}

Berdasarkan latar belakang yang telah diuraikan di atas, maka rumusan masalah dalam penelitian ini adalah Apakah ada pengaruh penggunaan metode diskusi kelompok dalam meningkatkan hasil belajar sosiologi siswa kelas XI SMAN 12 Makassar.

\section{Metode Penelitian}

a) Jenis Penelitian

Penelitian ini adalah penelitian tindakan kelas (Classroom Action Reseach). Penelitian terdiri atas serangkaian siklus, Setiap siklus meliputi 4 tahap yaitu perencanaan, tindakan, observasi, dan refleksi.

b) Subjek penelitian

Subjek dalam penelitian ini adalah siswa kelas XI SMAN 12 Makassar sebanyak 30 orang yang terdiri dari 20 siswa laki-laki dan 10 siswa perempuan

c) Prosedur Penelitian.

Rancangan penelitian tindakan kelas yang akan dilaksanakan terdiri atas dua atau lebih siklus, yakni siklus pertama, dan siklus kedua. Gambaran umum yang dilakukan pada setiap siklus adalah : Perencanaan, pelaksanaan, pengamatan, dan refleksi.

d) Teknik Pengumpulan Data

Tehnik pengumpulan data pada penelitian ini, yaitu: (1) Data mengenai keaktifan siswa mengikuti proses belajar mengajar diambil denganlembar observasi. (2) Data mengenai tingkat pemahaman siswa terhadap materi pelajaran setelah diadakantindakan, diambil dengan menggunakan tes hasil belajar sosiologi pada setiap akhirsiklus. (3) Data mengenai tanggapan siswa terhadap pelaksanaan tindakan yang digunakan,diambil dengan menggunakan lembar observasi dan melalui tanggapan pada akhirsiklus II. 
e) Teknik Analisis Data

Data yang diperoleh dalam penelitian ini adalah data tentangketerlaksanaan pembelajaran sosiologi dengan menggunakan pembelajaran metode diskusikelompok. Data yang terkumpul berupa data hasil observasi dan tes. Data hasil belajar siswa berupa tes akan dianalisis dengan menggunakan skor yang berdasarkan penilaian acuan patokan, dihitung berdasarkan skor maksimal yang mungkin dicapai oleh siswa. Nilai yang diperoleh dikelompokkan menjadi lima kategori yaitu sangat tinggi, tinggi, sedang, Rendah dan sangat rendah. Kriteria yang digunakan untuk menentukan kategori hasil belajar berdasarkan teknik kategorisasi yang ditetapkan oleh Departemen Pendidikan Nasional (Mardia, 2004: 20) yang dinyatakan sebagai berikut:Teknik Kategori Standar Berdasarkan Ketetapan DEPDIKNAS

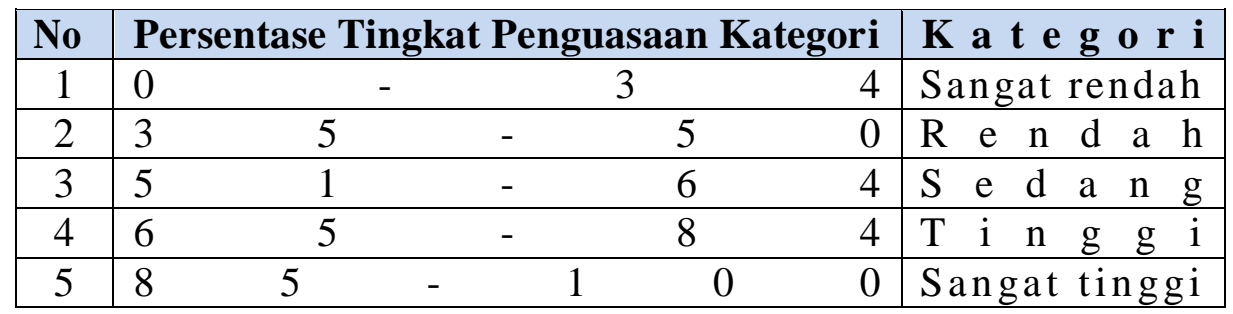

\section{B. TINJAUAN PUSTAKA}

\section{Pembelajaran Sosiologi}

Sosiologi ditinjau dari sifatnya digolongkan sebagai ilmu pengetahuan murni (pure science) bukan ilmu pengetahuan terapan (applied science). Sosiologi dimaksudkan untuk memberikan kompetensi kepada peserta didik dalam memahami konsep-konsep sosiologi seperti sosialisasi, kelompok sosial, struktur sosial, lembaga sosial, perubahan sosial, dan konflik sampai pada terciptanya integrasi sosial. Sosiologi mempunyai dua pengertian dasar yaitu sebagai ilmu dan sebagai metode. Sebagai ilmu, sosiologi merupakan kumpulan pengetahuan tentang masyarakat dan kebudayaan yang disusun secara sistematis berdasarkan analisis berpikir logis. Sebagai metode, sosiologi adalah cara berpikir untuk mengungkapkan realitas sosial yang ada dalam masyarakat dengan prosedur dan teori yang dapat dipertanggungjawabkan secara ilmiah.

Pembelajaran sosiologi dimaksudkan untuk mengembangkan kemampuan pemahaman fenomena kehidupan sehari-hari. Materi pelajaran mencakup konsepkonsep dasar, pendekatan, metode, dan teknik analisis dalam pengkajian berbagai fenomena dan permasalahan yang ditemui dalam kehidupan nyata di masyarakat. Mata pelajaran Sosiologi diberikan pada tingkat pendidikan dasar sebagai bagian integral dari 
Sosiologi, sedangkan pada tingkat pendidikan menengah diberikan sebagai mata pelajaran tersendiri.Mata pelajaran sosiologi bertujuan agar peserta didik memiliki kemampuan sebagai berikut: (a)Memahami konsep-konsep sosiologi seperti sosialisasi, kelompok sosial, struktur sosial, lembaga sosial, perubahan sosial, dan konflik sampai dengan terciptanya integrasi sosial.(b)Memahami berbagai peran sosial dalam kehidupan bermasyarakat. (c)Menumbuhkan sikap, kesadaran dan kepedulian sosial dalam kehidupan bermasyarakat.

\section{Hasil Belajar}

Menurut Catharina Tri Anni (2002:4) hasil belajar merupakan perubahan perilaku yang diperoleh pembelajar setelah mengalami aktivitas belajar. Hasil belajar juga merupakan kemampuan yang diperoleh siswa setelah melalui kegiatan belajar $(\mathrm{H}$. Nashar, 2004: 77). Hasil belajar adalah terjadinya perubahan dari hasil masukan pribadi berupa motivasi dan harapan untuk berhasil dan masukan dari lingkungan berupa rancangan dan pengelolaan motivasional tidak berpengaruh terdadap besarnya usaha yang dicurahkan oleh siswa untuk mencapai tujuan belajar (Keller H Nashar, 2004: 77).

Hasil belajar dapat di ukur dalam bentuk perubahan pengetahuan, sikap dan keterampilan, perubahan yang lebih baik dibandingkan sebelumnya misalnya dari tidak bisa menjadi bisa, dari tidak santun menjadi santun(Martinis yamin, 2003: 86). Berdasarkan teori-teori yang telah dikemukakan diatas, maka dapat disimpulkan bahwa hasil belajar adalah perubahan tingkah laku siswa secara nyata setelah dilakukan proses belajar mengajar yang sesuai dengan tujuan pengajaran.

\section{Metode Diskusi Kelompok}

a) Pengertian Metode Diskusi Kelompok

Menurut Tohirin (2007: 291) diskusi kelompok merupakan suatu cara dimana siswa memperoleh kesempatan untuk memecahkan masalah secara bersama-sama. Sedangkan Usman (2008:94) menyatakan bahwa diskusi kelompok merupakan suatu proses yang teratur yang melibatkan sekelompok orang dalam interaksi tatap muka yang informal dengan berbagai pengalaman atau informasi, pengambilan kesimpulan atau pemecahan masalah. Lebih lanjut Sukardi (2008:220) diskusi kelompok adalah suatu pertemuan dua orang atau lebih, yang ditunjukkan untuk saling tukar pengalaman dan pendapat, dan biasanya menghasilkan suatu keputusan bersama. 
Berdasarkan pendapat para ahli di atas, penulis menyimpulkan bahwa diskusi kelompok adalah metode yang memberi kesempatan kepada siswa untuk saling tukar pengalaman dan pendapat dalam memecahkan masalah secara bersama-sama.

b) Langkah-Langkah Metode Diskusi Kelompok

Menurut Rusman (2014:114) Metode diskusi dalam belajar memiliki langkahlangkah sebagai berikut:

1) Guru mengemukakan masalah yang akan didiskusikan danmemberikan pengarahan seperlunya mengenai cara-cara pemecahannya.

2) Dengan pimpinan guru, siswa membentuk kelompok diskusi, memilih pemimpin diskusi (ketua, sekretaris/ pencatat, pelapor), mengatur tempat duduk, ruangan sarana dan sebagainya.

3) Para siswa berdiskusi di kelompoknya masing-masing sedangkan guru berkeliling dari kelompok satu ke kelompok yang lain untuk menjaga serta memberi dorongan dan bantuan sepenuhnya agar setiap anggota kelompok berpartisipasi aktif supaya diskusi bejalan dengan lancar. Kemudian tiap kelompok diskusi melaporkan hasil diskusinya. Hasil-hasil diskusi yang dilaporkan ditanggapi oleh semua siswa (terutama bagi kelompok lain). Guru memberi ulasan dan menjelaskan tahap-tahap laporan-laporan tersebut.

4) Para siswa mencatat hasil diskusi tersebut dan guru mengumpulkan hasil diskusi dari tiap-tiap kelompok.

\section{HASIL PENELITIAN}

Pada bab ini dibahas tentang hasil-hasil penelitian setelah pelaksanaan metode diskusi kelompok pada siswa kelas XI SMAN 12 Makassar. Hasil penelitian tindakan kelas yang telah dilaksanakan meliputi hasil tes siklus I, hasil tes siklus II, dan hasil observasi.

\section{Hasil Tes Siklus I}

Pada tahap ini dilaksanakan proses observasi dan evaluasi terhadap pelaksanaan tindakan dengan menggunakan lembar observasi yang telah dibuat serta melaksanakan evaluasi berupa tes hasil belajar Siklus I setelah 3 kali pertemuan. Tes hasil belajar siswa yang diberikan berbentuk uraian sebanyak 5 item. Apabila hasil tes akhir siswa pada siklus I dianalisis, maka persentase ketuntasan belajar siswa tes akhir siklus I dapat dilihat pada tabel berikut. 


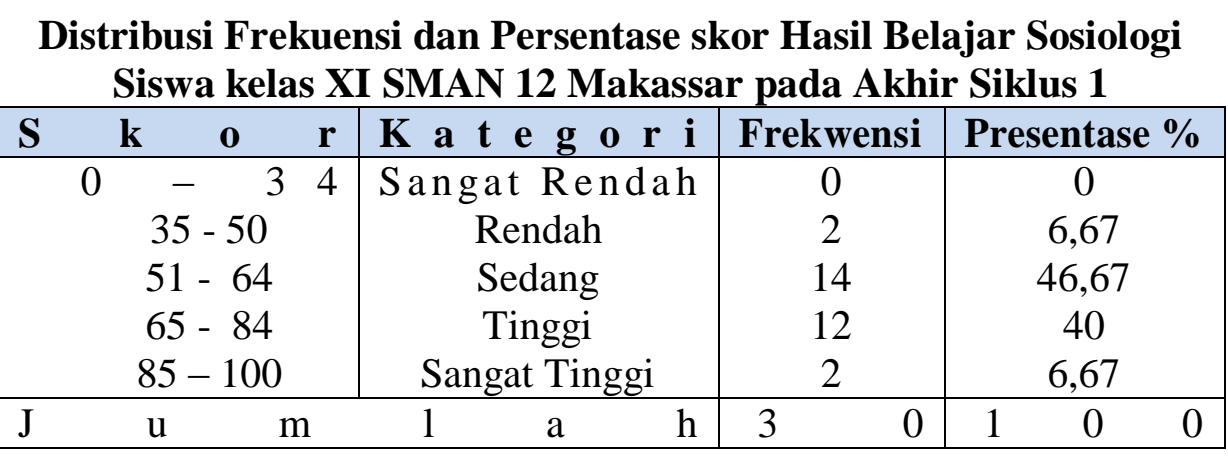

Berdasarkan tabel di atas dapat dikemukakan bahwa dari 30 siswa Kelas XI SMAN 12 Makassar terdapat 2 siswa atau sekitar 6,67\% yang tingkat hasil belajar pada kategori rendah, 14 siswa atau 46,67\% yang tingkat hasil belajar pada kategori sedang, 12 siswa atau sekitar $40 \%$ siswa yang tingkat hasil belajar pada kategori tinggi, dan pada kategori sangat tinggi ada 2 siswa atau sekitar 6,67\%.

\section{Ketuntasan Belajar Siklus I}

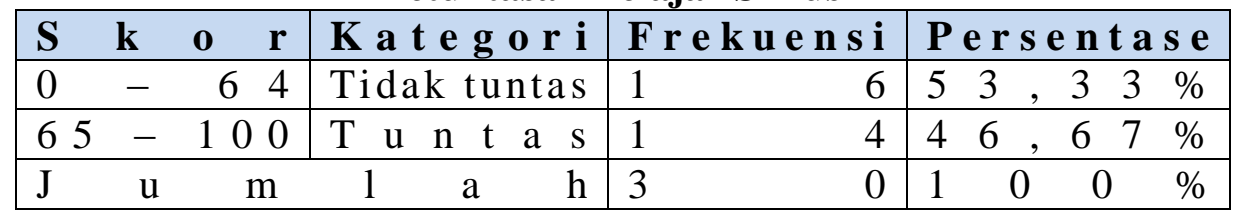

Dari tabel di atas, menunjukkan persentase ketuntasan belajar siswa Kelas XI SMAN 12 Makassarsebesar $46,67 \%$ atau 14 dari 30 siswa termasuk tuntas dan kategori tidak tuntas $53,33 \%$ atau 16 dari 30 siswa.

Berdasarkan hasil observasi diperoleh gambaran bahwa motivasi, keaktifan, minat, sikap serta perhatian siswa selama mengikuti kegiatan pembelajaran sosiologi diperoleh bahwa siklus I dari 30 siswa yaitu sebagai berikut;

a) Rata-rata persentase siswa yang hadir pada saat kegiatan pembelajaran sebanyak 90,83\%, lainnya tidak hadir karena alpa (tanpa keterangan)

b) Rata-rata persentase siswa yang memperhatikan pada saat proses pembelajaran sebanyak $85,83 \%$; lainnya siswa yang tidak memperhatikan pembahasan materi disebabkan karena tidak terlalu paham dengan materi yang diajarkan.

c) Rata-rata persentase siswa yang melakukan aktifitas negatif selama proses pembelajaran (main-main, ribut, dll) mencapai 5\%; disebabkan karena bosan dengan pelajaran sosiologi sehingga guru harus berusaha memotivasi siswa agar siswa menyukai pelajaran sosiologi. 
d) Rata-rata persentase siswa yang bertanya tentang materi pelajaran yang belum dimengerti adalah 15\%; yang lain disebabkan karena materi yang di ajarkan belum bisa kuasai oleh siswa, sehingga guru harulah berupaya membimbing siswa untuk mampu berpikir dan antusias dalam memecahkan masalah.

e) Rata-rata persentase siswa yang mengajukan pertanyaan atau tanggapan tentang materi diskusi mencapai $9,16 \%$; yang lainnya hanya diam karena tidak menguasai materi diskusi.

f) Rata-rata persentase siswa yang masih perlu bimbingan dalam prose pembelajaran $14,16 \%$; karena yang lainnya tidak merespon setiap pertanyaan yang diajukan.

g) Rata-rata persentase siswa yang memperhatikan penjelasan guru dan mencatat pada saat pemebelajaran 32,5\%; yang lainnya hanya diam tampa ada respon.

h) Rata-rata persentase siswa yang mengerjakan pekerjaan rumah sebanyak 32,5\%, yang lainnya malas, tidak tahu samasekali.

\section{Hasil Tes Siklus II}

Pada tahap ini dilaksanakan proses observasi dan evaluasi terhadap pelaksanaan tindakan dengan menggunakan lembar observasi yang telah dibuat serta melaksanakan evaluasi berupa tes hasil belajar Siklus II setelah 3 kali pertemuan. Tes hasil belajar siswa yang diberikan berbentuk uraian sebanyak 5 item. Jika skor prestasi hasil belajar sosiologi siswa pada siklus I tersebut dikelompokkan dalam 5 kategori, maka diperoleh distribusi frekuensi sebagai berikut.

\section{Distribusi Frekuensi dan Persentase skor Hasil Belajar Sosiologi} Siswa kelas XI SMAN 12 Makassar pada akhir Siklus II

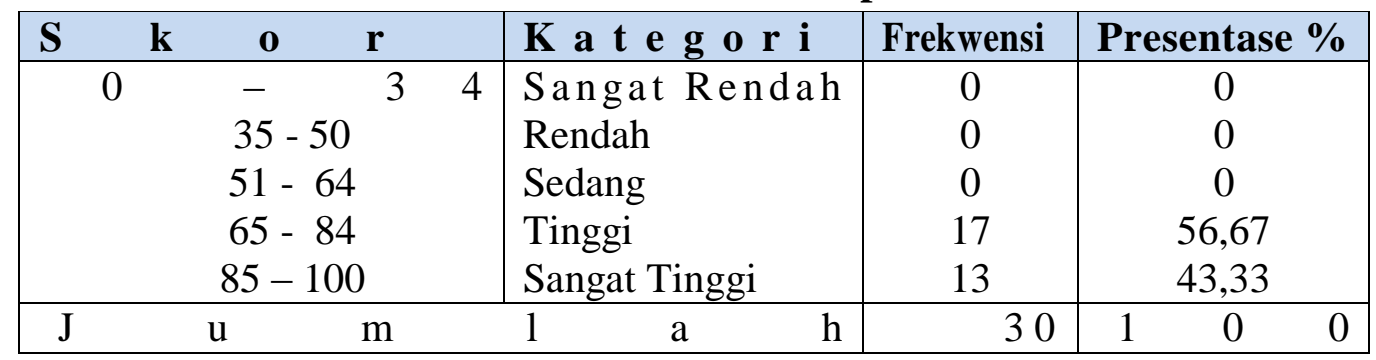

Berdasarkan di atas, dapat dikemukakan bahwa dari 30 siswa Kelas XI SMAN 12 Makassar terdapat 17 siswa atau sekitar 56,67 \% siswa yang tingkat hasil belajar pada kategori tinggi, dan pada kategori sangat tinggi ada 13 siswa atau sekitar 43,33\%.

\section{Ketuntasan Belajar Siklus II}

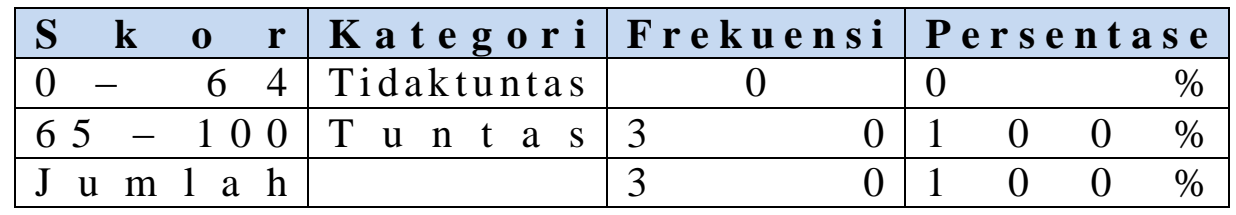


Dari tabel di atas, menunjukkan persentase ketuntasan belajar siswa Kelas XI SMAN 12 Makassarsebesar $100 \%$ atau 30 dari 30 siswa termasuk tuntas dan kategori tidak tuntas $0 \%$ atau 0 dari 30 siswa.

Berdasarkan hasil observasi diperoleh gambaran bahwa aktivitas dan kehadiran siswa selama mengikuti kegiatan pembelajaran sosiologi semakin meningkat. Dari hasil analisis deskriptif terhadap skor hasil belajar siswa setelah diterapkan metode pemberian tugas selama berlangsungnya diperoleh bahwa pada siklus II dari 30 siswa yaitu sebagai berikut;

a) Rata-rata persentase siswa yang hadir pada saat kegiatan pembelajaran sebanyak 95\% ,tanpa ada keterangan alpa, izin, sakit.

b) Rata-rata persentase siswa yang memperhatikan pada saat proses pembelajaran sebanyak 91,66\%; ada yang tidak memperhatikan karena tidak mengerti apa yang di jelaskan oleh guru.

c) Rata-rata persentase siswa yang melakukan aktifitas negatif selama proses pembelajaran (main-main, ribut, dll) 4,16\%; ada siswa yang bosan, jenuh,keluar masuk ruangan.

d) Rata-rata persentase siswa yang bertanya tentang materi pelajaran yang belum dimengerti adalah $11,66 \%$; ada siswa yang hanya diam, tanpa memperhatikan materi pembelajaran, ada yang belum kuasai materi.

e) Rata-rata persentase siswa yang mengajukan pertanyaan atau tanggapan tentang materi diskusi yang belum dimengerti mencapai 9,16\%; karena masih banyak siswa yang belum sempat membaca materi dari kelompok lain.

f) Rata-rata persentase siswa yang masih perlu bimbingan dalam proses pembelajaran sebanyak 18,33\%; masih ada siswa yang belum merespon pertanyaan yang diajukan.

g) Rata-rata persetase siswa yang memberikan tanggapan terhadap materi dari kelompok lain mencapai $67,18 \%$, karena ada siswa tidak memperhatikan pemateri yang membahas materinya.

h) Rata-rata persentase siswa yang mengerjakan pekerjaan rumah sebanyak $70,83 \%$.ada siswa yang malas, lupa atau tidak tahu sama sekali.

\section{PEMBAHASAN}

Pembelajaran dengan pendekatan model kooperatif mendorong siswa untuk belajar lebih aktif dan lebih bermakna, artinya siswa dituntut selalu berfikir tentang suatu persoalan dan mereka mencari sendiri cara penyelesaiannya. Dengan demikian mereka akan lebih 
terlatih untuk selalu menggunakan keterampilan pengetahuannya, sehingga pengetahuan dan pengalaman belajar mereka akan tertanam untuk jangka waktu yang cukup lama. Pelaksanaan pembelajaran dengan pendekatan model kooperatif meliputi lima langkah, yaitu: (1) Menyampaikan tujuan dan memotivasi siswa. (2) Menyajikan informasi. (3) Mengorganisasikan siswa dalam kelompok-kelompok belajar. (4) Membimbing kelompok agar bekerja dan belajar. (5) Evaluasi.

Dalam penelitian ini, pembelajaran sosiologi dengan pendekatan model kooperatif dilakukan dengan setting kelompok. Abdul Asis Wahab (2007:39) mengatakan bahwa: Teknik diskusi kelompok adalah salah satu teknik belajar yang dilakukan oleh seorang guru di sekolah. Didalam diskusi ini proses belajar mengajar terjadi dimana interaksi antara dua atau lebih individu yang terlibat, saling tukar menukar pengalaman, informasi, memecahkan masalah, dapat terjadi juga semuanya aktif, tidak ada yang pasif sebagai pendengar saja. Pembagian kelompok dilakukan oleh guru, dengan membentuk kelompok yang bersifat heterogen dalam hal kemampuan akademik dan jenis kelamin. Siswa dibagi menjadi beberapa kelompok, yang masing-masing beranggotakan 4 orang siswa. Dengan diskusi kelompok memungkinkan siswa untuk berbagi informasi dalam menyelesaikan masalah dan dapat memandang penyelesaian masalah dengan berbagai sudut pandang yang berbeda.

Hasil analisis data ketuntasan belajar siswa dapat dilihat pada grafik tersebut di bawah ini :

Grafik Persentase Ketuntasan Belajar Siswa Siklus I dan II

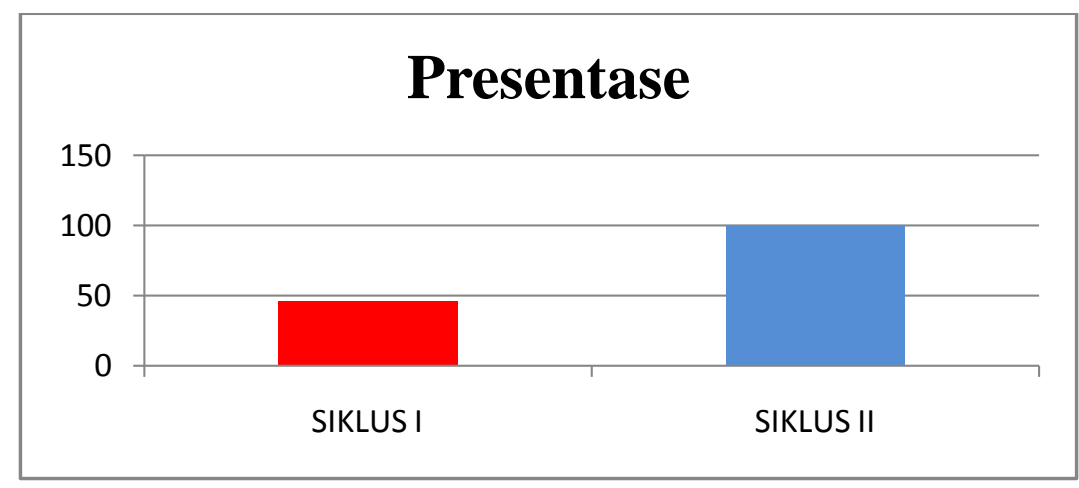

Dari grafik perbandingan di atas dapat kita lihat bahwa persentase ketuntasan pada siklus I siswa yang tuntas dalam pembelajaran diskusi kelompok ada 14 orang siswa atau 46,67\%. Dari grafik ini dapat kita lihat bahwa persentase ketuntasan hasil belajar sosiologi belum dapat memenuhi target yang diharapkan pada siklus I, oleh karena itu dilakukan perbaikan pada siklus II. Dari grafik perbandingan diatas dapat kita lihat bahwa pada siklus II mengalami peningkatan persentase ketuntasan hasil belajar sosiologi dengan menggunakan 
pembelajaran diskusi kelompok ada 30 orang siswa atau dari siklus I dengan Persentase 46,67\% meningkat menjadi $100 \%$ yakni pada siklus II.

Pada pertemuan ke-1 siklus I, tidak ada siswa yang berani untuk maju ke depan kelas, sehingga guru harus menunjuk perwakilan kelompok yang akan mempresentasikan jawabannya. Siswa juga belum berani untuk bertanya dan mengungkapkan pendapatnya. Namun pada pertemuan berikutnya siswa sudah mulai berani untuk mempresentasikan jawabannya, dan memberikan tanggapan atas hasil presentasi. Setelah presentasi selesai, guru meminta siswa membuat kesimpulan dari hasil presentasi. Kemudian guru memberi penguatan atas kesimpulan yang dibuat oleh siswa, dan membuat rangkuman dari materi yang dipelajari. Pada akhir setiap siklus dilaksanakan tes individu. Berdasarkan hasil analisis tes pada siklus I dan siklus II, kemampuan penalaran belajar sosiologi siswa kelas XI SMA MRM mengalami peningkatan.

\section{E. KESIMPULAN DAN SARAN}

1. Kesimpulan

Berdasarkan analisis data dan pembahasan, maka dapat ditarik kesimpulan bahwa hasil belajar sosiologi siswa kelas XI SMAN 12 Makassar mengalami peningkatan setelah diadakan pembelajaran dengan metode diskusi kelompok, dengan indikasi sebagai berikut:

a) Melalui implementasi metode diskusi kelompok maka aktifitas, minat, perhatian, dan motivasi belajar siswa kelas XI SMAN 12 Makassar pada pembelajaran sosiologi dapat ditingkatkan, hal ini terlihat dari adanya peningkatan jumlah kehadiran siswa, serta peningkatan jumlah siswa yang memperhatikan materi pada saat proses belajar mengajar berlangsung, semakin banyak siswa yang mampu memecahkan masalah dan semakin banyaknya siswa yang mengacungkan tangan saat diskusi.

b) Melalui implementasi metode diskusi kelompok maka hasil belajar siswa kelas XI SMAN 12 Makassar pada pembelajaran sosiologi dapat ditingkatkan. Setelah diberikan tindakan pada siklus I berada dalam kategori sedang dengan skor rata-rata 63,66 dari skor ideal 100 dengan standar deviasi 16,64. Dan setelah diberikan tindakan pada siklus II berada dalam kategori tinggi dengan skor rata-rata 78,33 dari skor ideal 100 dengan standar deviasi 7,73. 


\section{Saran}

Sehubungan dengan hasil penelitian ini, maka beberapa saran untuk dimengerti sebagai berikut :

a) Guru diharapkan mampu memberikan bimbingan, mengarahkan dan menerangkan strategi pembelajaran dengan menggunakan metode diskusi kelompok kepada siswa untuk meningkatkan prestasi belajar sosiologi

b) Siswa, untuk mencapai prestasi yang baik, tidak hanya tergantung pada tingkat intelektual saja, melainkan juga dipengaruhi oleh kemampuan berinteraksi.

c) Peneliti-peneliti mendatang tentang masalah ini, diharapkan penelitian selanjutnya dapat menindak lanjutkan penelitian dengan memberikan instrumen yang telah lengkap dan menggunakan populasi yang lebih luas dengan mempertimbangkan variabel-variabel dan memperhatikan faktor-faktor lain yang mempengaruhi kemampuan berinteraksi siswa dalam prestasi belajar sosiologi.

\section{DAFTAR PUSTAKA}

Arikunto, Suharsimi. 2013. Dasar-Dasar Evaluasi Pendidikan. Jakarta: PT Bumi Aksara

Djamarah, Bahari Syaiful dan Zain, Aswan. 2006 Strategi Belajar Mengajar, Cet. III; Jakarta: Rineka Cipta

Dimyati dan Mudjiono. 2009. Belajar dan Pembelajaran. Jakarta : PT. Rineka Cipta

Hamalik, Oemar. 2002. Psikologi Belajar dan Mengajar. Bandung : Sinar Baru Algensindo.

Irawan,Prasetya. 2001. Teori-Teori Pembelajaran, Cet 1: Jakarta : PT. Rineka Cipta.

Kasmadi \& Sunariah Siti Nia. 2013. Panduan Modern Penelitian Kuantitatif. Bandung: Alfabeta

Mulyasa, E. 2008 Menjadi Guru Profesional, Cet. VII. Bandung: Rosdakarya

Munandar, Utami. 2013. Psikologi Belajar. Jakarta: PT Raja Grafindo Persada.

Margono. 2010. Metodologi Penelitian Pendidikan. Jakarta: PT Rineka Cipta.

Nasution, S. 2003. Berbagai Pendekatan dalam Proses Belajar dan Mengajar. Jakarta: Bumi Aksara.

Purwanto. 1999. Penelitian Tindakan Kelas. Jakarta: Depdiknas 
Rusman. 2010. Model-Model Pembelajaran Mengembangkan Profesionalisme Guru. Jakarta: Rajawali Pers.

Salahudin, Anas. 2015. Penelitian Tindakan Kelas. Bandung :Cv Pustaka Setia

Sardiman. 2011. Interaksi dan motivasi belajar mengajar. Jakarta : PT Raja Grafindo Persada.

Sanjaya, Wina. 2006. Strategi Pembelajaran Berorientasi Standar Proses Pendidikan. Jakarta : Kencana Predana Media Group.

Slameto. 1995. Belajar Dan Faktor-Faktor Yang Mempengaruhinya. Jakarta: Rineka Cipta.

Soekanto Soejono. 2010. Sosiologi Suatu Pengantar. Jakarta: Rajawali Pers

Taneko, Soleman. 1984. Ilmu-Ilmu Sosial. Jakarta : PT. Raja Grafindo Persada.

Wirawan. 2013. Teori-Teori Sosiologi Dalam Tiga Paradigma (Fakta Sosial, Definisi Sosial \& Perilaku Sosial). Jakarta: Kencana Prenadamedia Group

Zulkarnain, W. 2013. Dinamika Kelompok (Latihan Kepemimpinan Pendidikan). Jakarta: PT Bumi Aksara. 